\title{
THE JOURNAL OF
}
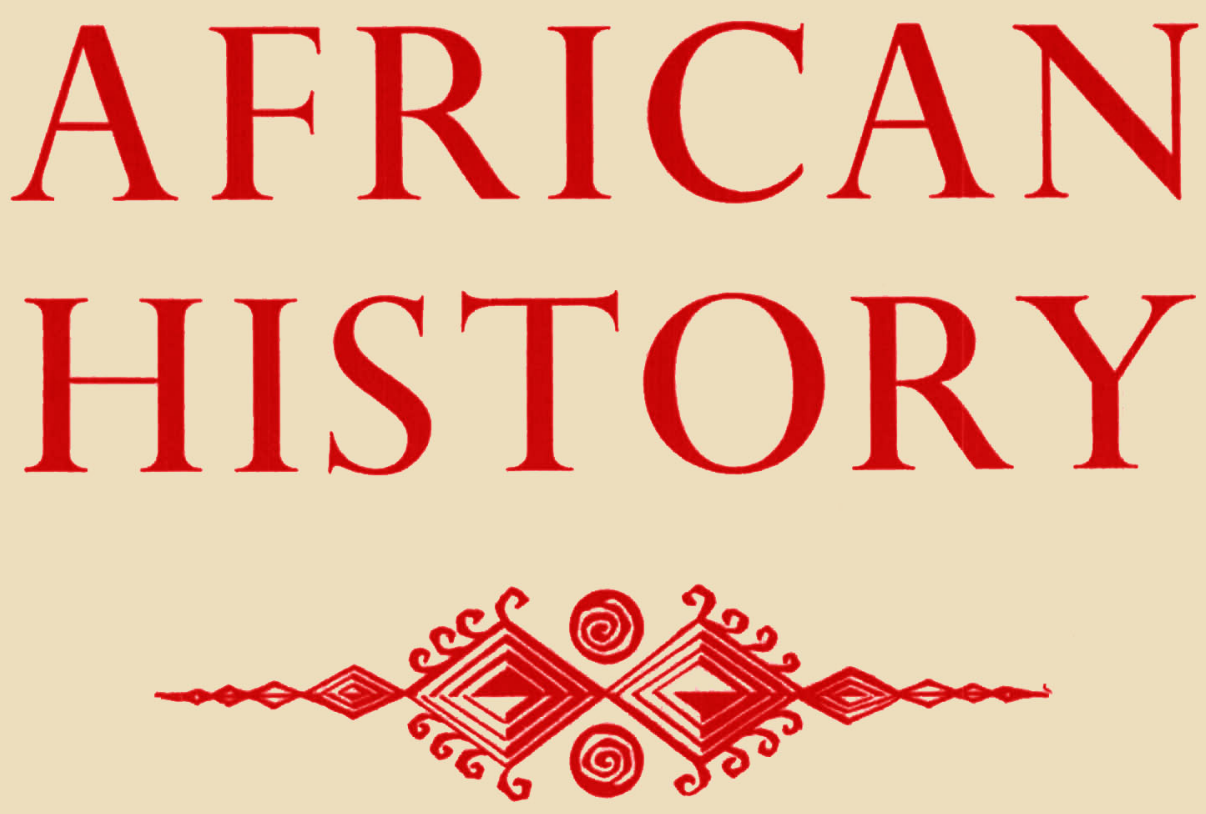

\section{EDITED BY}

MICHAEL BRETT, MICHAEL CROWDER, J. FORBES MUNRO, ANDREW ROBERTS

$$
\text { VOLUME } 28 \cdot 1987 \cdot \text { NUMBER } 2
$$

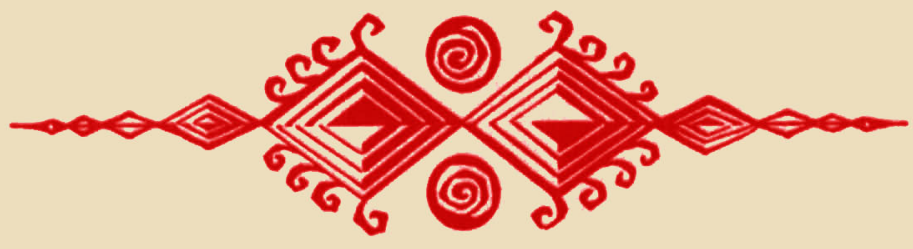

CAMBRIDGE UNIVERSITY PRESS 
ADVISORY EDITORIAL BOARD

\author{
A. I. Asinaju (University of Lagos) \\ C. J. BUNDY (University of \\ Cape Town) \\ J. D. FAGE (University of \\ Birmingham) \\ H. J. Fisher (S.O.A.S., London) \\ C. FYFE (University of \\ Edinburgh) \\ A. G. HoPKINs (University of \\ Birmingham) \\ R. LAw (University of Stirling)
}
P. Lovejoy (York University, Ontario)
G. MURIUK I (University of Nairobi)
R. A. Ol.iver (S.O.A.S., London)
M. PosnansKy (University of California, Los Angeles)
M. TALBI (University of Tunis)
J. VANSINA (University of Wisconsin, Madison)
J. L. VELLUT (Université Catholique de Louvain)

C) Cambridge University Press 1987

SUBSCRIPTIONS

The Gournal of African History (ISSN $002 \mathrm{I}-8537$ ) is published three times a year. Single parts $£_{1} 12.00$ net (US $\$ 29.00$ in the USA and Canada).

Three parts form a volume. The subscription price of volume 28, 1987 (which includes postage) is $£ 35.00$ net (US $\$ 8_{3} .00$ in the USA and Canada) for institutions; $\oint_{1} 8.50$ (US $\$ 40.00$ in the USA and Canada) for individuals ordering direct from the Press and certifying that the Journal is for their personal use.

Orders, which must be accompanied by payment, may be sent to a bookseller or to the publisher: Cambridge University Press, The Edinburgh Building, Shaftesbury Road, Cambridge CB2 2RU or in the USA and Canada, to Cambridge University Press, 32 East 57 th Street, New York, NY 10022 . Copies of the journal for subscribers in the USA and Canada are sent by air to New York to arrive with minimum delay. Second class postage paid at New York, NY, and at additional mailing offices. POSTMASTER: send address changes in USA and Canada to The fournal of African History, Cambridge University Press, 32 East 57th Street, New York, NY 10022.

Articles appearing in this journal are annotated and indexed in Historical Abstracts and America : History and Life.

\section{COPYING}

This Journal is registered with the Copyright Clearance Center, 2 I Congress Street, Salem, Mass. o1970. Organizations in the USA who are also registered with C.C.C. may therefore copy material (beyond the limits permitted by sections 107 and 108 of US copyright law) subject to payment to C.C.C. of the per-copy fee of \$05.00. This consent does not extend to multiple copying of promotional or commercial purposes. Code $0021-8537 / 87 / 01$ \$05.00.

ISI Tear Service, 3501 Market Street, Philadelphia, Pennsylvania 19104, USA, is authorized to supply single copies of separate articles for private use only.

For all other use, permission should be sought from Cambridge or the American Branch of Cambridge University Press.

\section{PUBI.ISHED BY}

THE PRESS SYNDICATE OF THE UNIVERSITY OF CAMBRIDGE

The Pitt Building, Trumpington Street, Cambridge CB2 IRP

32 East 57 th Street, New York, NY 10022 , USA

10 Stamford Road, Oakleigh, Melbourne 3166 , Australia 